\title{
一方通航型水路における速力規制のあり方について
}

\author{
臼井 英夫*・謝 洪彬 ${ }^{* *} \cdot$ 井上 欣三* ${ }^{*}$ 朴 榮守***
}

\section{A Study for a Design Method of Speed Control on One-way Passage}

\section{Hideo USUI, Hongbin XIE, Kinzo INOUE and Young-Soo PARK}

\begin{abstract}
Speed control of ships in a narrow waterway is a useful measure for improving safety of ships in narrow waterway. To ensure the effect of speed control, it is necessary to analyze the merit and the demerit of speed control from the viewpoint of objective assessment. However, there is no tool to establish a design method for speed control based on objective judgment.

In this paper, a new marine traffic simulation program is developed. In this program, judgments for collision avoidance and movements of ships on a one-way passage are well considered to simulate actual situations in a narrow waterway. And, the Environmental Stress Model is introduced to evaluate difficulties of ship maneuvering of results of marine traffic simulation. Finally, the relationships among unacceptable ratios with speed control and the ratios without speed control are obtained.
\end{abstract}

This design method will be a good solution for an administrator of a narrow waterway when he will consider that speed control should be set or not.

Keywords: Collision Avoidance, Marine Traffic Simulation, Waterway Design, Safety Assessment Technology キーワード: 避航㨐船, 交通流シミュレーション, 水路設計, 安全評価技術

\section{1.はじめに}

日本国内における主要な狭水道では、海上交通安 全法に基づき、船舶は 12 ノットを超えて航行して はならない区間が定められている。この速力規制は 輻輳する狭水道における事故発生防止のために、船 舶速力を一定以下として、船舶交通流を整流させる 効果を期待したものと見ることができる。

しかしながら、近年の船舶の大型化、高速化に伴 い安全性向上のための方策であった速力規制が、 相対速力差が小さいために追い越しが完了するまで に長時間を要したり、先船に引き続くための団子状 態を引き起こしたりするといった速力規制によるマ
イナス面も現れ始めている。

速力規制については、既に研究事例(1),(2)が見られ るものの、避航操船を考虑した上で、体系的に狭水 路における速力規制のあり方は検討されていない。 そこで、本研究では、一方通行とした水路において、 速力規制を行うべきかどうかを操船困難性の観点か ら系統的に解析し、整理する。

\section{2. 追い越し・追い抜きを考虑した狭水路 交通流シミュレーション \\ 2.1 誰隔距離の設定}

避航操船を考慮した交通流シミュレーションにつ

\footnotetext{
* 正会員 神戸大学海事科学部 （テ625-0022 神戸市東灘区梁江南町 5-1-1） usui@maritime.kobe-u.ac.jp

** 学生会員 神戸大学大学院自然科学研究科海事科学専攻

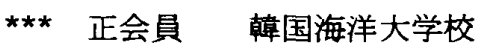




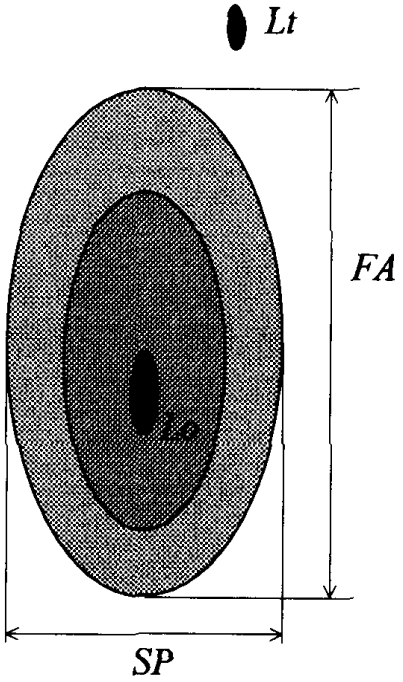

Fig. 1 Setting of avoidance area

いては、過去の研究事例が多く見られる ${ }^{(3),(4)}$ 。しか しながら、多くが輻輳する海域において、横切り関 係に対する避航を主として取り扱っており、追い越 しに関する考慮はあまりされていない。また、水路 側端に対する扱いが十分されているとはいえない。 そこで本研究では、追い越し、追い抜きを対象とし た上で、水路側端の取り扱いを考慮した避航アルゴ リズムを用いた交通流シミュレーションを実施した。 避航判断を行うにあたっては、Fig.1 に示すように、 自船の周囲に他船との間に確保したい距離をもった 楕円をバンパーとして設定した ${ }^{(5)}$ 。

航過距離は、安全上決して他船に侵害されたくな い最小限の領域を意味する限界航過距離と、この距 離以遠で航過他船には何の不安も感じない領域を意 味する十分航過距離の 2 種類とし、自船と他船の船 長に従い、以下の関係式で求まるものとした。

$$
\begin{aligned}
& F A \text { (限界 })=(0.015 L t+2.076) L o \\
& S P(\text { 限界 })=(0.008 L t+0.667) L o \\
& F A \text { (十分 })=(0.025 L t+3.125) L o \\
& S P(\text { 十分 })=(0.012 L t+1.096) L o \\
& \text { ただし、 }
\end{aligned}
$$$$
F A \text { (限界):限界航過前方距離(m) }
$$$$
S P \text { (限界):限界航過左右距離(m) }
$$$$
F A \text { (十分):十分航過前方距離(m) }
$$$$
S P \text { (十分):十分航過左右距離(m) }
$$$$
L o: \text { 自船船長 }(\mathrm{m})
$$$$
L t: \text { 他船船長 }(\mathrm{m})
$$

バンパーエリアの中心は自船位置から自船船長の $10 \%$ 前方とした。

\section{2 船舶の発生、初期速力の設定}

船舶の発生について、船型、発生時間、発生位置 を決定することになる。船型については、あらかじ
め与えられた船型毎の発生比率をもとに、一様乱数 を用いて船型を決定する。発生時間については、あ らかじめ与えられた平均発生時間間隔をもとに、指 数分布を仮定して決定する。発生位置については、 水路中央を平均位置とし、水路中央から水路幅まで を標準偏差の 2 倍とした正規分布を仮定して決定す る。

初期速力については、船型毎にあらかじめ与えら れている平均速力と標準偏差を用いて、正規分布を 仮定して標準偏差の 2 倍までの範囲で決定する。こ のとき、速力規制があるときには、求められた速力 が制限速力以上である場合、初期速力を制限速力と した。

\section{3 避航アルゴリスムの設定}

直線上の水路における追い越し、追い抜きを考慮 した交通流シミュレーションを実現するためには、 船舶の発生、初期速力の設定の他に、避航アルゴリ ズムとして、以下の 5 つのステップでの判断、決定 を行う必要がある。

(1) 避航の要否の判定

自船より前方にある他船の速力が自船よりも遅い 場合に避航する必要があると判定する。

(2) 避航開始時期の判断

自船の十分前方航過距離まで他船が接近した時を、 避航開始時期とする。

（3）避航行動の決定・実行

自船の限界左右航過距離以上の距離をもって他船 を航過できる場合はそのまま追い抜きを行う。

他船と水路側端との間隔が自船の限界左右航過距 離より広い場合は変針避航を行う。変針角は $30^{\circ}$ に設定した。このとき、他船の右側を追い越すか、 左側を追い越すかについては、他船と水路側端との 間隔がより広い方へ変針することとした。

自船の縦限界航過距離まで近づき、かつ他船と水 路側端との間隔が自船の限界左右航過距離より狭い 場合は、衝突の恐れのある他船と同じ速力となるよ う減速避航を行う。

(4) 復針時期の判断・実行

追い越し開始後、他船との横距離が限界左右航過 距離以上となった時、原針路に復針する。

(5) 水路側端への接近の回避

避航開始後、水路側端までの横距離が自船長以下 となった場合、水路側端に接近したとして、原針路 に復針する。

シミュレーション実施時には、計算対象となって いる全船が、上記の判断決定を毎秒行うこととした。 


\section{4 船的の操墥運動モデル}

船舶の操綐運動モデルとして、旋回角速度、船速、 操舵を以下の運動方程式で示すような一次遅れ系で 表現した。

$$
\begin{aligned}
& T \dot{r}+r=K \delta \\
& T_{V} \dot{V}+V=V_{o r d e r} \\
& T_{E} \dot{\delta}+\delta=\delta_{\text {order }} \\
& \text { ただし、 } \\
& \quad V: \text { 船速 }(\mathrm{m} / \mathrm{s}) \\
& \quad V_{\text {order }} \text { :指令船速 }(\mathrm{m} / \mathrm{s}) \\
& r: \text { 㳬回角速度 }(\mathrm{rad} / \mathrm{s}) \\
& \delta: \text { 舵角 }(\mathrm{deg}) \\
& \delta \text { order } \text { :指令舵角 }(\mathrm{deg}) \\
& K, T: \text { 操綐性指数 } \\
& T_{E}: \text { 操舵機の時定数 } \\
& T_{V} \text { :船速の時定数 }
\end{aligned}
$$

各船舶の操縦性指数と時定数については、船型毎 にあらかじめ与えられた平均值と標準偏差を用いて、 正規分布を仮定して、発生船舶每に異なる性能を与 えることとした。

\section{3. シミュレーションシステムの概要}

2.2 で説明した避航アルゴリズムのもとで、交通 流シミュレーションを行うためのプログラムを開発 した。開発環境には Borland C++ Builder 6.0 Professional を用い、動作環境はMS-Windows とした。 Fig.2 に開発した交通流シミュレーションシステム の外観を示す。

システムは大別してメニュー部と表示部の $2 つ か$ ら構成されている。

(1) $メ ニ ュ ー$ 部

システム上部にメニューを配置した。項目として、 [File]、[Options]、[Run]、[Pause]の 4 種類とした。 各項目の機能を以下に示す。

File：計算に使用する水路形状、交通流条件を記 述したファイルを指示する。

Options : 避航操船のあるなし、速力規制のあるな しを設定する。

Run：シミュレーション計算の開始を指示する。

Pause：計算途中における一時休止を指示する。

(2) 表示部

システムの下部に配置した表示部はさらに、画面 右側に配置した計算中の船舶の動きをグラフィカル に表示する部分と、グラフィック表示画面の視点を 移動・拡大させるためのボタンを配置した操作部が ある。

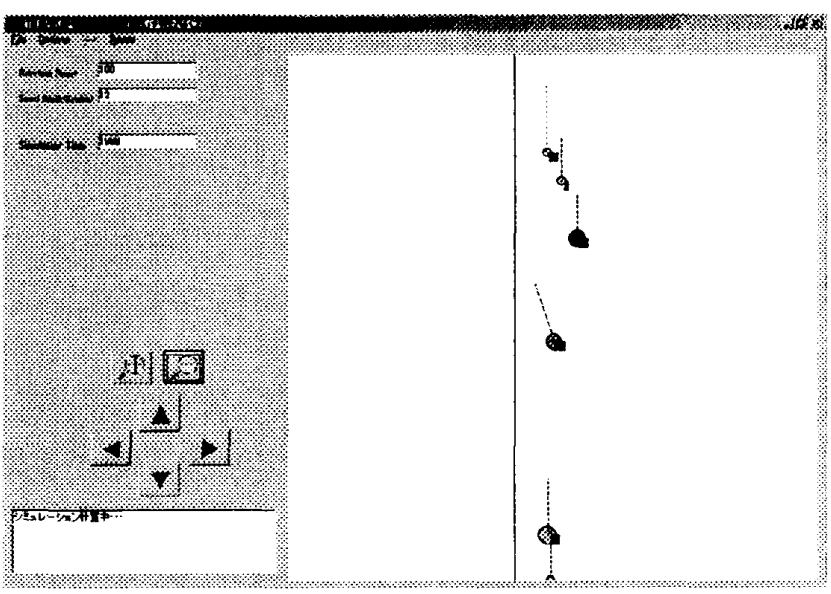

Fig.2 Overview of traffic simulation system

また、交通流シミュレーションの計算を行うため に必要となる乱数の種と、速力規制を行う場合の設 定速力を入力できるようにした。

グラフィック表示画面では、発生した船舶は船長 を直径とする円で表示される。また、各船舶の速力、 針路に応じたベクトルを表示する。

そして、通常航行中、他船接近中、避航中、復針 中といった操船状態に応じて、船舶を意味する円の 表示色を変えることで、プログラム実行中に船舶の 動きを把握しやすいように工夫した。

\section{4. 操船困難性から見た速力規制のあり方 4.1 羁境ストレスモデルによる操船困難性の 算出方法}

環境ストレスモデルは、操船者に課される困難性 を客観的、定量的に評価するために開発されたモデ ルである ${ }^{(6)}$ 。環境ストレスモデルにより出力される ストレス值は、操船者に課される困難性を 0 から 1 ００００までの值の範囲で示すものである。ストレ ス値の算出方法は、自船の原針路を中心として士 $90^{\circ}$ の範囲で、 $1^{\circ}$ 毎に針路を変えたとしたときに、 陸岸への乗り上げ又は他船との衝突に対して操船者 の感じる危険感を、全く安全であれば 0 、非常に危 険であれば 6 とした 7 段階の尺度で求める。この $1^{\circ}$ 毎に得られた 0 から 6 までの危険感を自船の原 針路を中心とした $\pm 90^{\circ}$ の範囲で積算し、その操 船局面におけるストレス值とする。環境ストレスモ デルの下では、護岸、防波堤など周辺の地形から操 船者に課される困難性を操船環境ストレスとし、他 船から課される困難性を交通環境ストレスとしてい る。

本研究は、速力規制の有無によって船舶交通流の 状況が変化し、それに伴って操船者に課される困難 性も変化するであろうことから、交通環境ストレス 值を評価指標とすることによって、速力規制の実施 
効果や功罪を操船困難性の観点から定量的に明らか にしようとするものである。

\section{2 計算条件}

シミュレーションの条件設定として、発生船舶の 船型構成、全長、速力の分布は、参考文献(1)と同じ とした。評価対象水路は Fig.3 に示すように、直線 状水路とし、図の下側から上側一の一方通航とした。

船舶の発生隻数を $10 ， 20 ， 30$ 隻/時の 3 種

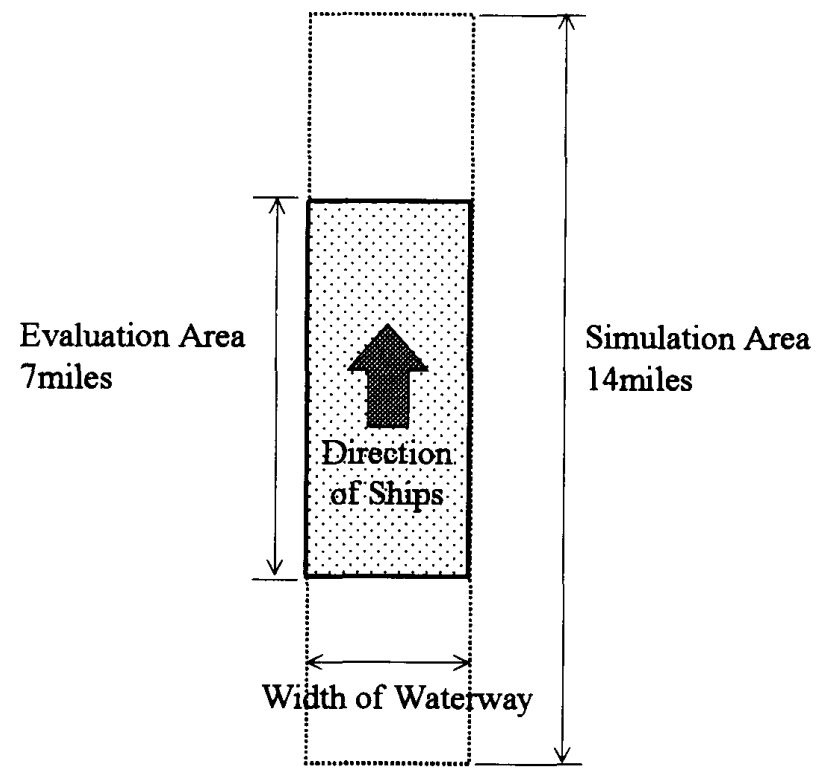

Fig.3 Arrangement of waterway

類、水路幅を $400,700,1000 \mathrm{~m}$ の 3 種類、 制限速力を 12 ノットとした。シミュレーション時 間を 7 時間とし、最初と最後の 1 時間を除いた 5 時 間の交通流データを評価に用いた。乱数の初期值を 変えて 5 回シミュレーションを行い、都合 25 時間 分の評価計算を 15 秒間隔で行った。ただし、分析 に際しては、 5 時間平均に引き直して整理した。

\section{3 計算结果}

Fig.4 は、発生隻数を 30 隻／時、水路幅を $400 \mathrm{~m}$ として、ある船舶に着目したときの、速力規制のあ る場合（図中では W/ Speed Limit と表記）と、無い 場合（図中ではW/O Speed Limit と表記）における 交通環境ストレス值の時間変化を示している。

Fig.4の中で、速力規制のない場合を実線で、速力 規制のある場合を点線で示している。この図から、 速力規制のあるなしによって、船舶の航行状況が変 化し、それに伴って自船の操船者に課される負荷を 意味する交通環境ストレス值も変化する様子が分か る。

環境ストレスモデルにおいては、環境ストレス値



Fig.4 An example of changes of ESs value

が 750 以上となると、その状況は操船者にとって 許容できないという対応付けがなされている ${ }^{(6)}$ 。そ こで、本研究では、一連のシミュレーション計算の 過程における全船舶に対して、環境ストレスモデル を適用し、交通環境ストレス值を求め、時々刻々求 められたストレス値全体の中で 750 以上の值とな る割合をもって評価することとした。

Fig.5 は、水路幅を $400 ， 700 ， 1000 \mathrm{~m}$ と したときの船舶発生隻数と交通環境ストレス值が 7 50 以上となる割合との関係を、避航操船のある時 と無いときについて示している。

いずれの水路幅においても、発生隻数が増えるに つれて、交通環境ストレス值が 750 以上となる割 合が増加することが分かる。また、同じ発生隻数と した場合では、水路幅を広げることにより、交通環 境ストレス值が 750 以上となる割合が低下するこ とが分かる。これらは、水路を航行する際に課され る操船者の困難性をうまく表現できているといえる。

速力規制の効果について着目すると、水路幅 40 $0 \mathrm{~m}$ およ゙ $700 \mathrm{~m}$ 場合については、速力規制の ない方が速力規制のある時に比べ、交通環境ストレ ス値が 750 以上となる割合が、どの発生隻数にお いても高い。このことは、狭い水路で速力規制のな い場合には、速力の速い船舶が遅い他船に接近して も追い越すことができず、結果として船舶が集まっ て航行するような団子状態となり、操船者に課す負 荷が増加していることを表していると言え、速力規 制を設定することによって操船者の負荷を楥和して いることとなる。

一方、 $1000 \mathrm{~m}$ の場合の結果に着目すると、発 生隻数が少ない場合には、 $400 \mathrm{~m} 、 700 \mathrm{~m}$ の結 果と同様に、速力規制のない場合の方がある場合に 比べ交通環境ストレス值が 750 以上となる割合が 高いが、発生隻数の増加に伴い、その関係が逆転し ていることが分かる。これは、発生隻数の増加によ 


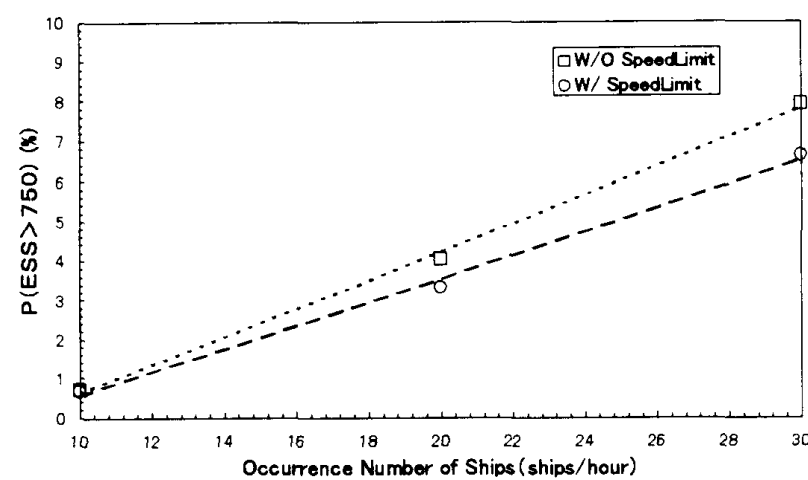

(a) Width of waterway: $400 \mathrm{~m}$

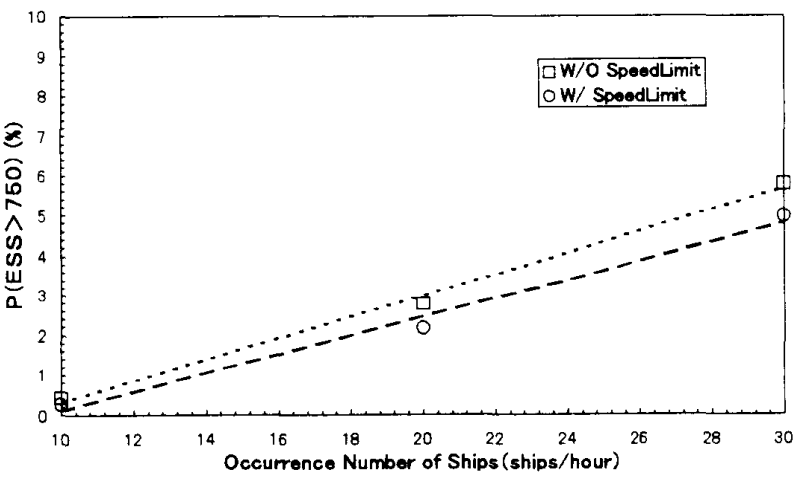

(b) Width of waterway: $700 \mathrm{~m}$



(c) Width of waterway: $1000 \mathrm{~m}$

Fig. 5 Results of calculation

り、追い越しの機会も増えるものの、水路幅が広い 場合には他船の横を追い越せる水域が確保できるた めに団子状態とならずに航行できることによる。

これらのことから速力規制の効果は、水路幅と船 舶の発生隻数との関係により、操船者に課される困 難性を考虑して、その功罪を判断することができる ことが分かった。

そこで Fig.6に、発生隻数を 30 隻/時としたと きの、水路幅と交通環境ストレス值が 750 以上と なる割合との関係について、Fig.5 の結果からプロッ トし直したものを示す。

この図より、水路幅が狭い場合には速力規制を行 った方が操船者に課す困難性を低くでき、水路幅が 広くなれば速力規制を行った方が操船者に課す困難 性が高くなることが分かる。そして、速力規制を行 うべきかどうかの判断は、両者の関係が逆転すると

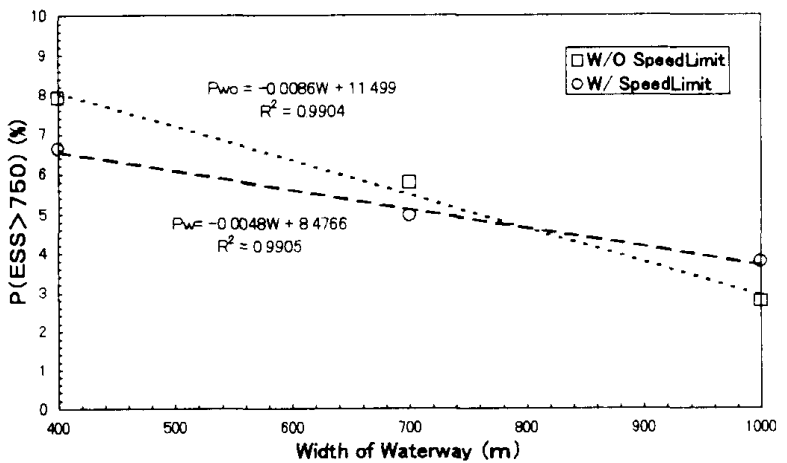

Fig.6 Relations between width of waterway and difficulty of maneuverability

ころ、すなわち今回設定した交通流条件のもとでは 水路幅 $800 \mathrm{~m}$ を目安とすることができる。

\section{5. おわりに}

これまで、一方通航型水路を設定した上で、速力 規制を課すかどうかについての定量的な判断材料が 無かつたため、速力規制の実施効果や功罪について は分からない部分が多かった。

本研究では、この問題について、まずは一方通航 型水路における船舶交通流シミュレーションプログ ラムを開発した。その上で、得られた交通流データ に対し、環境ストレスモデルを適用して、操船者に 課される困難性の観点から、速力規制の効果を明ら かとした。そして、与えられた交通条件のもとで速 力規制を課すべきかどうかの判断ができるようにし た。その結果、交通量が少ない場合には、困難性の 観点から見ると速力規制を行った方が良い。しかし ながら、交通量が多くなると、水路幅の広い場合に は速力規制を行わない方が困難性の観点からは良い ことが分かった。このことから、速力規制を行うか どうかは、主として交通量に依存するといえる。

本研究の結果は、操船者およひ水路の安全管理者 両者にとって、共通の土台に立った管理設計を行う ことができる意味から重要である。

\section{参考文献}

（1）朴 笨守・井上欣三:狭水路における速力規制 の功罪検証, 日本航海学会論文集, 第 106 号, pp.79-86, 平成 14 年 3 月

（2）水井真治 - 岩崎寛希 - 辻 啓介 - 笹 健児:備 讃瀬戸航路における速力規制に関する基礎的 研究,日本航海学会論文集, 第 112 号, pp.49-55, 平成 17 年 3 月

（3）長澤 明:避航を考虑した海上交通シミュレー ション，航海，第 80 号, pp.28-34, 昭和 59 年 6 月

(4) 長谷川和彦・桐谷誠司・立川功二:輻輳海域シ ミュレーターによる代替航路評価,関西造船協 
会講演概要集,第 16 号, pp.71-74, 平成 13 年 5 月

（5）井上欣三・宇佐美 茂・柴田登紀子:制約水域 における航過距離と離隔距離に関する操船者 のモデル化, 日本航海学会論文集, 第 90 号, pp.297-306, 平成 6 年 3 月

（6）井上欣三・増田憲司・世良 亘海上交通安全 評価のための技術的ガイドライン策定に関す る研究ーI 一環境負荷の概念に基づく操船 の困難性評価一, 日本航海学会論文集, 第 98 号, pp.225-234, 平成 10 年 3 月

\section{翼疑応答}

水井真治（広島商船高等専門学校）:

航路内の速力規制のあり方は、発表で提案された操 船者に課す困難性という、いわばミクロ手法の検討 のみではなく、水域全体を対象としたマクロ手法の 検証が必要ではないかと考えています。

この観点について、いかがお考えでしょうか?

臼井英夫 :

今回の検討では、水域全体において航行した全船舶 を対象とした評価計算を行っており、特定の水域や 船舶に着目した評価ではありません。一方、評価の 観点としては、困難性のみならず、危険性や経済性 といった検討も必要であると考えておりますので、 設計指針となるよう総合的な検討を今後していく所 存です。 